\title{
Physical Indicators of Cambisols Under Agricultural Uses in Chapada do Apodi, Semiarid Region of Brazil
}

\author{
Joseane Dunga da Costa ${ }^{1}$, Jeane Cruz Portela ${ }^{1}$, Phâmella Kalliny Pereira Farias ${ }^{1}$, José Francismar de Medeiros ${ }^{1}$, \\ Pollyana Mona Soares Dias ${ }^{1}$, Stefeson Bezerra de Melo ${ }^{1}$, Rafael Oliveira Batista ${ }^{1}$, \\ Joaquim Emanuel Fernandes Gondim ${ }^{1} \&$ Matheus Alves Ribeiro ${ }^{1}$ \\ ${ }^{1}$ Universidade Federal Rural do Semi-Árido, Campus Pau dos Ferros e Mossoró, Brazil \\ Correspondence: Jeane Cruz Portela, Universidade Federal Rural do Semi-Árido, Campus Pau dos Ferros e \\ Mossoró, Av. Francisco Mota, 572, Bairro Costa e Silva, CEP: 59.625-900, Mossoró, RN, Brazil. Tel: \\ 55-(84)-996-933-669. E-mail: jeaneportela@ufersa.edu.br; joseane.costa@ufersa.edu.br
}

Received: October 5, 2019

doi:10.5539/jas.v12n6p170
Accepted: May 1, $2020 \quad$ Online Published: May 15, 2020

URL: https://doi.org/10.5539/jas.v12n6p170

\begin{abstract}
Soil physical structure is related to porous space dynamics, which is affected by pedogenetic conditions, land uses, and agricultural practices. Thus, the objective of this work was to evaluate physical and structural attributes of Cambissolos under different uses in the Terra de Esperança Settlement Project, in Chapada do Apodi, Governor Dix-Sept Rosado, Rio Grande do Norte, Brazil, and detect the most sensitive attributes for the distinction of environments using multivariate analysis. The study areas with different land uses were: Native Forest Area 1 (NFA1), Native Forest Area 2 (NFA2), Native Forest Area 3 (NFA3) (reference areas), Conventional Management Area (CMA) Agroecological Area (AEA), and Cajaraneira (Spondia sp.) Orchard Area (COA). Areas with agricultural uses were characterized through physical and structural analyses, using disturbed and undisturbed soil samples collected from their 0.00-0.10, 0.10-0.20, and 0.20-0.30 m soil layers. The soil classes of the areas, according to the Brazilian Soil Classification System (SiBCS) were Cambissolo Haplico Carbonatico vertissolico (NFA1); Cambissolo Haplico Ta Eutrofico tipico (NFA2 and COA); Cambissolo Haplico Ta Eutrofico vertissolico (NFA3); and Cambissolo Haplico Carbonático tipico (CMA and AEA). The results of the attributes analyzed were expressed as mean of three replications per soil layer of each area, using multivariate analysis. Soil textures varied from sandy clay loam to clay. The total sand fraction presented negative correlations with clay dispersed in water, gravimetric moisture (GM), volumetric moisture (VM), total porosity determined (TPd) and microporosity (MiP); and positive correlations with soil density (SD), and basic infiltration rate (BIR), denoting pedogenetic influence. The SD presented significant correlation with GM, VM, TPd, MiP, macroporosity (MaP), aeration porosity (AP) and BIR, denoting its importance for the physical structure of the soil, and its dynamics. The most relevant attributes for the discrimination of the soil physical structure were the inorganic fractions clay and sand, porosity, degree of flocculation, aggregates, and soil mechanical resistance to penetration. The physical and structural attributes of the Cambissolos Haplicos were generally preserved, when compared to the current conditions of the NFAs, despite the different land use and managements. However, the soils of NFA1 (0.20-0.30 m layer), CMA, and AEA areas indicate fragility in aggregate stability and degree of flocculation due to the predominance of the sand fraction. The COA presented more favorable physical and structural conditions to the development of agricultural crops, especially on the surface layers, mostly influenced by their clay, TPd, AP, GM, VM, and soil mechanical resistance to penetration.
\end{abstract}

Keywords: structure, inorganic fractions, native forest, pedogenetic conditions

\section{Introduction}

Soil dynamics are affected by pedogenetic conditions, land uses, and managements due to the traffic of machines and implements used in conventional soil preparation for crops (Oliveira et al., 2013). Physical and structural attributes of adequate soils allow processes of water infiltration, retention, and availability to plants, and gas and heat exchanges with the atmosphere and roots of plants; these soils respond to management and resist to degradation, providing adequate conditions for the growth and development of plants (Reichert et al., 2003). The performance of these soils and the maintenance of their productive capacity cannot be directly measured, however, it can be estimated using some physical attributes, which are used as indicators when they are sensitive 
to different uses over time, and shows the effect of land use changes (Pereira et al., 2011; D'andréa et al., 2002), since physical quality improvement is connected to chemical and biological soil attributes (Dexter, 2004; Araújo et al., 2007).

The main soil physical indicators are texture, structure, and their related attributes-aggregate stability, porosity, density, resistance to root penetration, and water infiltration and retention (Araújo et al., 2012). Physical and structural attributes of the soil are influenced by pedogenetic conditions and the management of the soil and crops used, consequently, soils present different potentials and limitations.

A proper soil management promotes the maintenance or little alterations in the soil physical properties, allowing the good development of the crops. The alteration of these characteristics can generate problems, such as compaction, reduction in soil water infiltration and retention, porosity, and aggregation (Junior Pereira, 2010). Therefore, studying the dynamics of soil properties is important, especially in areas where the soil is subjected to different uses, since they can indicate management options, and show the soil attribute responses to different soil management practices (Santos et al., 2009).

In this context, the objective of this work was to evaluate physical and structural attributes of Cambissolos under different uses in the Terra de Esperança Settlement Project, in Chapada do Apodi, Governor Dix-Sept Rosado, Rio Grande do Norte, Brazil, and detect the most sensitive attributes for the distinction of environments using multivariate analysis.

\section{Methodology}

\subsection{Study Area}

The research was carried out in the Terra da Esperança Settlement Project (TESP), southeastern municipality of Governador Dix-Sept Rosado (12 km from the city's downtown), state of Rio Grande do Norte, Brazil, in the Chapada do Apodi microregion (Figure 1). Governador Dix-Sept Rosado has an area of 1,263 $\mathrm{km}^{2}$. The climate of the region is BSh, semi-arid hot, according to the Köppen climate classification (Alvares et al., 2013); it has annual average rainfall of $712 \mathrm{~mm}$ from February to May, natural vegetation of hyper-xerophilous Caatinga, which includes deciduous species, i.e., species that tend to lose leaves in dry seasons. The soil of this region are predominantly Cambissolos (Jacomine et al., 1971).

The TESP has 6,297 hectares divided into three agro-villages with 113 family farmers who have 30 hectares each. These farmers were settled in 1998; the land was granted by the National Institute of Colonization and Agrarian Reform (INCRA).

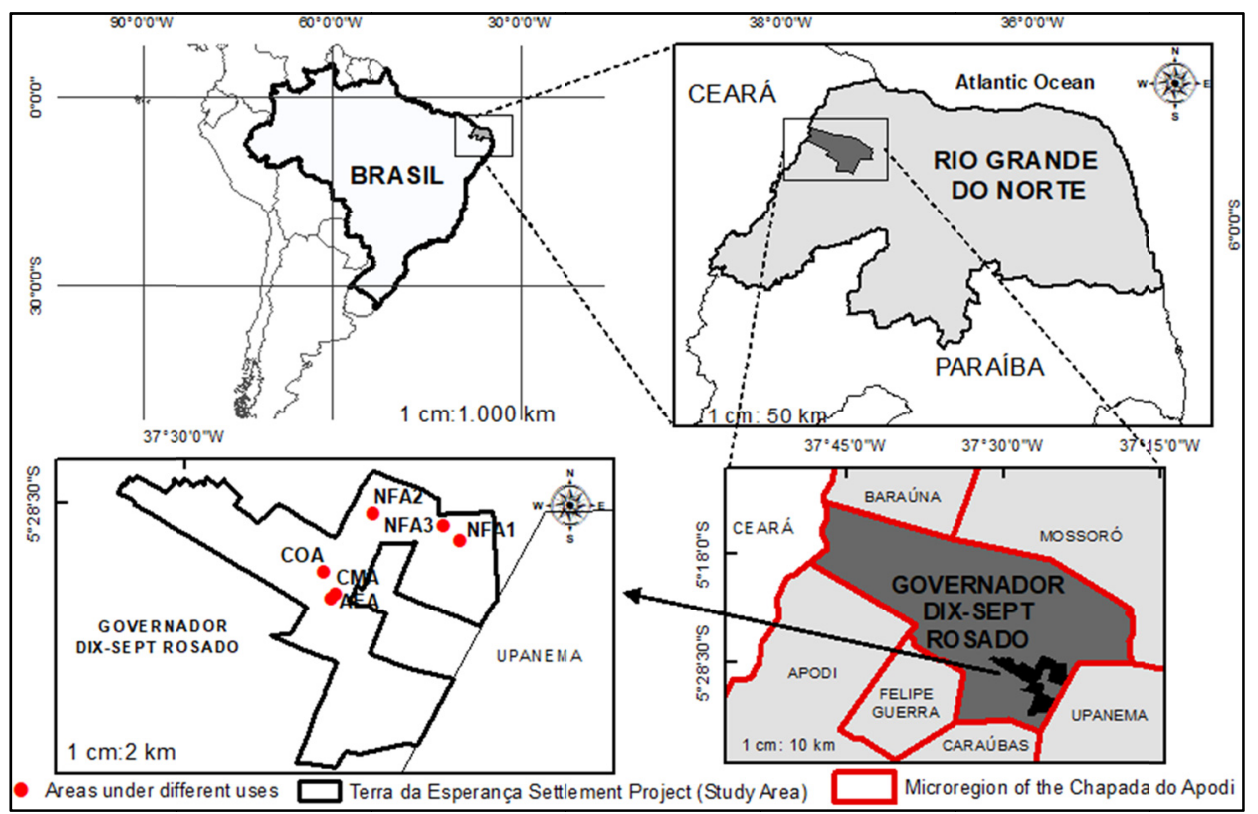

Figura 1. Location of the study area: Terra da Esperança Settlement Project, Governador Dix-Sept Rosado,

Chapada do Apodi microregion, state of Rio Grande Grande do Norte, Brazil 
Six sites were chosen for the research (Figure 1):

$>$ Native Forest 1, 2, and 3 (NFA1, NFA2, and NFA3): environmental reserve areas with preserved hyper-xerophilous Caatinga vegetation, which includes deciduous species, favoring the input of organic matter; this area had some wood removed for fencing of other areas. In the dry periods, these areas were used for grazing animals (goats) raised by the settlers. These areas were used as reference areas because of the reduced anthropogenic influence, to compare changes in soil attributes, simulating natural environment conditions.

> Conventional Management Area (CMA): area with maize, string beans, sesame, pumpkin, and sorghum crops grown in the rainy season, with no irrigation. No burning practices and no chemical fertilizers had been applied in this area since 2005, however, soil management were conducted using plowing and harrowing. This area was fallow during the study period.

> Agroecological area (AEA): area established in 2005 to produce fruits and forage for the subsistence of the family farmers, and animals, and had production of honey by Africanized bees. Some agroecological soil conservation practices were used in this area, such as: absence of burning practices, preservation of natural succession of the plants (using fruit species that are adapted to the semiarid), and control of erosive processes by using ridges that soften the surface runoff.

$>$ Cajaraneira (Spondia sp.) orchard area (COA): area with cajaraneiras, a fruit species of the genus Spondia, which were planted by the former owner in the 1970s. This species had great economic importance for the settlers; it produces about 2.8 to $3.2 \mathrm{Mg}$ of fruits per week at the peak harvest. This area had great contribution of organic matter to the soil during the dry season due to the leaf loss the of the Spondia sp.

The soils classes found in these areas, according to the Brazilian Soil Classification System (Santos et al., 2013) were: Cambissolo Haplico Carbonatico vertissolico (NFA1); Cambissolo Haplico Ta Eutrofico tipico (NFA2 and COA); Cambissolo Haplico Ta Eutrofico vertissolico (NFA3); and Cambissolo Haplico Carbonático tipico (CMA and AEA).

\subsection{Soil Sampling}

Disturbed and undisturbed soil samples from the 0.00-0.10, 0.10-0.20, and 0.20-0.30 m layers were collected in the areas considering 1 ha for each area, and taken to the Soil Physics for Analysis of Soil, Water, and Plant of the Agricultural Sciences Center of the Federal Rural University of the Semi-arid Region. Five composed samples of disturbed soil were formed from 15 subsamples that were collected using a Dutch auger and packed in identified plastic bags. These samples were air dried, disaggregated and passed through a $2 \mathrm{~mm}$ mesh sieve to obtain the air-dried fine earth (TFSA). Undisturbed samples were collected by opening four small random trenches in each area; two samples were collected in each of the three soil layers, using the volumetric ring method (rings of $5.0 \mathrm{~cm}$ in height and $5.0 \mathrm{~cm}$ in diameter), totaling 144 samples, and one undisturbed block by trench (04) per area (06) per layer (03), totaling 72 samples, which were packed in plastic bags.

\subsection{Physical Indicators}

The results of the physical and chemical analyzes were expressed as means of three replications. Disturbed samples were analyzed for particle size, particle density, dispersed clay in water, degree of flocculation, and silt to clay ratio; undisturbed samples were analyzed for soil density, macroporosity, microporosity (tension table at $6 \mathrm{kPa}$ ), total porosity determined, soil aggregate, and stability of the undisturbed soil block to determine its weighted mean diameter (WMD), and geometric mean diameter (GMD), and soil water content (gravimetric, and volumetric moistures), according to Teixeira et al. (2017).

The soil granulometry was evaluated by the pipette method using chemical dispersant (sodium hexametaphosphate) and distilled water in $20 \mathrm{~g}$ of the air-dried fine earth under slow mechanical agitation on a shaker (Wagner $50 \mathrm{rpm}$ ) for 16 hours. The sand fraction $(2$ to $0.05 \mathrm{~mm})$ was determined by sieving, clay $(<0.002$ $\mathrm{mm}$ ) by sedimentation, and silt $(0.05$ to $0.002 \mathrm{~mm})$ by the difference between the sand and clay fractions; the silt to clay ratio was also calculated. Particle density analysis was performed using the volumetric flask method using the air-dried fine earth in an oven at $105^{\circ} \mathrm{C}$, and ethyl alcohol.

Dispersed clay in water was determined by slow mechanical dispersion in water with shaking for $16 \mathrm{~h}$ at $50 \mathrm{rpm}$, followed by separation of the clay fraction by sedimentation of the silt. The degree of flocculation was obtained by the naturally dispersed clay to total clay ratio.

Soil density was determined by the volumetric ring method, using a ring with known volume, with means represented by the quotient of the soil solid particle weight by the total soil volume. 
Undisturbed samples were saturated for 48 hours and weighed to determine total porosity. Subsequently, they were placed in a tension table saturated with water and without air bubbles in the column at tension of $6 \mathrm{kPa}$ to determine microporosity. The soil macroporosity was determined by the difference between total porosity and microporosity.

The soil aggregate distribution was determined by the wet sieving technique. The samples were sieved in 4.76 , $2.00,1.00,0.50,0.25,0.105$, and $0.053 \mathrm{~mm}$ mesh sieves, immersed in water and shaken in a mechanical oscillator for $15 \mathrm{~min}$. Soil aggregates were separated into size classes of 4.76 to $2.0,2.0$ to $1.0,1.0$ to $0.50,0.50$ to $0.25 \mathrm{~mm}$, and $<0.25 \mathrm{~mm}$. The WMD, and GMD of soil aggregates were calculated based on these results.

Soil mechanical resistance to penetration (SRP) was determined using a penetrometer (SoloStar PLG 5500, Falker) in 15 points of each study area. This device has an automatic measuring system, cone diameter of 12.83 $\mathrm{mm}$, resolution of $0.02 \mathrm{MPa}$; maximum of $90 \mathrm{kgf}$ supported by the rod, and maximum depth of $40 \mathrm{~cm}$, complying with the ASAE S.313.3 standards (ASAE, 2004), and simultaneous use of GPSMAP (Garmin 64s) for georeferencing, considering the mean SRP in the $0.0-0.10 \mathrm{~m}, 0.10-0.20$, and $0.20-0.30 \mathrm{~m}$ soil layers.

Soil water infiltration was evaluated by the ring infiltrator method with three replications per study site, using two concentric cylinders - height of $40 \mathrm{~cm}$ and diameters of $30 \mathrm{~cm}$, and $50 \mathrm{~cm}$ for the internal and external rings, respectively - with manual water supply for the cylinders, and readings of the water height $(\mathrm{cm})$ at $0,1,2,3,4,5$, $10,20,30,45,60,90$, and 120 minutes, or up to the equilibrium point to determine the basic infiltration rate (BIR) of water into the soil, according to Bernardo et al. (2008).

Deformed samples were collected from the $0.00-0.10,0.10-0.20$, and $0.20-0.30 \mathrm{~m}$ soil layers to perform gravimetric moisture (GM) analysis, since SRP and BIR are dependent on cohesion and adhesion forces, according Teixeira et al. (2017).

\subsection{Statistical Analysis}

Data of physical attributes were expressed by averages of three replications per layer and subjected to multivariate statistical analysis techniques to detect the most sensitive attributes for the distinction of soil environments under different uses, in the Statistica 7.0 program (STATSOFT, 2004), including correlation matrix, principal component, clustering, and factorial analyses, considering values of 0.65 for significant factor loads.

The layers $0.00-0.10 \mathrm{~m}(1), 0.10-0.20 \mathrm{~m}(2)$, and $0.20-0.30 \mathrm{~m}(3)$ in the areas under different uses were used to evaluated the variables-Native Forest Area 1 (NFA1-1, NFA1-2, and NFA1-3); Native Forest Area 2 (NFA2-1, NFA-2, and NFA-3); Native Forest Area 3 (NFA-1, NFA3-2, and NFA3-3); Area with Conventional Management System (CMA1, CMA2, and CMA3); Agroecological Area (AEA-1, AEAO-2, and AEA-3); Cajaraneira (Spondia sp.) Orchard Area: COA-1, COA-2, and COA-3).

Reference ranges of the most important variables of factorial analysis were used to interpret the results, according to Kiehl (1979), Arshad et al. (1996), Prevedello (1996), Reynolds et al. (2002), Reichert et al. (2003), Pereira et al. (2010), Ferreira (2010), and Prado (2013). The soils were classified according to their physical performance degree as good, regular, or poor.

\section{Results and Discussion}

\subsection{Soil Physical Indicators}

The textural classification of Cambissolos Haplicos (Table 1) showed sandy clay loam to clay soils, with granulometric composition with predominance of the sand fraction for the Native Forest Area 1 in the third soil layer (0.20-0.30 m) (NFA1), Conventional Management (CMA), and Agroecological (AEA) areas, presenting sand contents of 518 to $685 \mathrm{~g} \mathrm{~kg}^{-1}$, characterizing them as sandy clay loam texture, denoting primary minerals that are more resistant to the weathering process. Marinho et al. (2016) evaluated organic matter, and physicochemical attributes of a Cambissolo under different agricultural uses in the Chapada do Apodi microregion and found predominance of the sand fraction in areas with native forest, collective intercrops under conventional soil management, and in an agroecological area, with similar results, ranging from 426.1 to $660.5 \mathrm{~g}$ $\mathrm{kg}^{-1}$ (Table 1).

The soil of the NFA1-3, CMA, and AEA presented the highest particle densities due to the predominance of the quartz mineral in the solid fraction, with a density of $2.65 \mathrm{~g} \mathrm{~cm}^{-3}$; and the lowest total porosity, microporosity, and aggregate stability because solid particles are less susceptible to aggregation in coarser soils. Soil density is usually higher in sandy than in clayey soils; sandy soils have fewer micropores (internal pores of the aggregates) and thus, lower total porosity (Brady \& Weil, 2013), mechanical resistance to penetration, and gravimetric, and 
volumetric moistures. However, the soils presented higher rates of basic infiltration, especially the CMA and AEA, due to their homogeneity and predominance of the sand fraction in surface and subsurface layers (Table 1).

Table 1. Physical indicators of Cambissolos under different land uses in the Terra da Esperança Settlement Project, Governador Dix-Sept Rosado, Rio Grande do Norte, Brazil

\begin{tabular}{|c|c|c|c|c|c|c|c|c|c|c|c|c|c|c|c|c|c|c|}
\hline Soil layer & Sand & Silt & Clay & CDW & $\mathrm{DF}$ & Textural & $\mathrm{Dp}$ & $\mathrm{SD}$ & GM & $\theta$ & TPd & $\mathrm{MiP}$ & $\mathrm{MaP}$ & $\mathrm{AP}$ & WMD & GMD & SRP & BIR \\
\hline $\mathrm{m}$ & --- & $---g$ & $\mathrm{~kg}^{-1}$ & ----- & $\%$ & classification & $--\mathrm{gc}$ & $m^{-3}--$ & $\mathrm{g} \mathrm{g}^{-1}$ & $\mathrm{~cm}^{3} \mathrm{~cm}^{-3}$ & ---- & ----- 0 & 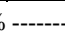 & ---- & $-----\mathrm{mn}$ & n ----- & $\mathrm{MPa}$ & $\mathrm{cm} \mathrm{h}^{-1}$ \\
\hline \multicolumn{19}{|c|}{ Native Forest Area 1 (NFA1)_Cambissolo Haplico Carbonatico vertissolico } \\
\hline $0.00-0.10$ & 476 & 173 & 351 & 284 & 19.09 & sandy clay & 2.23 & 0.96 & 0.29 & 0.28 & 61.89 & 53.03 & 8.86 & 27.32 & 1.76 & 1.86 & 2.01 & \\
\hline $0.10-0.20$ & 447 & 105 & 448 & 323 & 27.90 & clay & 2.14 & 1.23 & 0.25 & 0.31 & 6.17 & 47.82 & 8.35 & 23.32 & 1.19 & 0.77 & 1.70 & 1.89 \\
\hline $0.20-0.30$ & 541 & 94 & 365 & 280 & 23.29 & sandy clay loam & 2.44 & 1.31 & 0.17 & 0.22 & 47.23 & 38.67 & 8.56 & 18.89 & 1.36 & 0.97 & 1.33 & \\
\hline \multicolumn{19}{|c|}{ Native Forest Area 2 (NFA2)_Cambissolo Haplico Ta Eutrofico tipico } \\
\hline $0.00-0.10$ & 495 & 97 & 408 & 336 & 17.67 & sandy clay & 2.42 & 1.33 & 0.22 & 0.30 & 53.61 & 49.34 & 4.27 & 23.31 & 1.99 & 0.95 & 2.23 & \\
\hline $0.10-0.20$ & 438 & 143 & 419 & 368 & 12.12 & clay & 2.41 & 1.18 & 0.33 & 0.40 & 54.22 & 49.14 & 5.09 & 23.07 & 2.26 & 0.94 & 2.12 & 11.14 \\
\hline $0.20-0.30$ & 402 & 134 & 464 & 433 & 6.72 & clay & 2.32 & 1.22 & 0.27 & 0.33 & 52.05 & 47.44 & 4.60 & 23.11 & 2.26 & 0.61 & 1.76 & \\
\hline \multicolumn{19}{|c|}{ Native Forest Area 3 (NFA3)_Cambissolo Haplico Ta Eutrofico vertissolico } \\
\hline $0.00-0.10$ & 509 & 126 & 365 & 261 & 28.63 & sandy clay & 2.25 & 0.94 & 0.31 & 0.30 & 59.63 & 55.76 & 3.88 & & 2.67 & 0.67 & 1.53 & \\
\hline $0.10-0.20$ & 482 & 158 & 360 & 323 & 10.22 & sandy & 2.34 & 1.30 & 0.13 & 0.16 & 51.98 & 48.86 & 3.12 & 24.03 & 2.05 & 0.93 & 3.36 & 5.89 \\
\hline $0.20-0.30$ & 351 & 113 & 536 & 414 & 22.81 & clay & 2.53 & 1.31 & 0.15 & 0.20 & 59.01 & 55.04 & 3.97 & 26.77 & 3.11 & 2.18 & 2.38 & \\
\hline \multicolumn{19}{|c|}{ Area with Conventional Management System (CMA)_Cambissolo Haplico Carbonático tipico } \\
\hline $0.00-0.10$ & 613 & 130 & 257 & 222 & 13.70 & sandy clay loam & 2.35 & 1.56 & 0.12 & 0.18 & 42.27 & 41.33 & 2.45 & 21.67 & 1.44 & 1.06 & 1.48 & \\
\hline $0.10-0.20$ & 562 & 90 & 348 & 251 & 27.87 & sandy clay loam & 2.52 & 1.43 & 0.16 & 0.22 & 48.51 & 42.59 & 5.92 & 21.16 & 1.18 & 0.90 & 2.72 & 13.87 \\
\hline $0.20-0.30$ & 518 & 181 & 301 & 230 & 23.50 & sandy clay loam & 2.73 & 1.53 & 0.16 & 0.25 & 47.62 & 41.70 & 5.91 & & 1.21 & 0.78 & 1.90 & \\
\hline \multicolumn{19}{|c|}{ Agroecological area (AEA)—Cambissolo Haplico Carbonático tipico } \\
\hline $0.00-0.10$ & 685 & 84 & 231 & 188 & 18.61 & sandy clay loam & 2.85 & 1.53 & 0.14 & 0.22 & 41.62 & 39.98 & 1.64 & 19.68 & 1.95 & 1.59 & 2.27 & \\
\hline $0.10-0.20$ & 581 & 102 & 317 & 209 & 34.07 & sandy clay loam & 2.58 & 1.59 & 0.13 & 0.19 & 42.98 & 39.74 & 3.24 & 19.69 & 1.44 & 0.18 & 0.80 & 21.19 \\
\hline $0.20-0.30$ & 587 & 167 & 246 & 213 & 13.41 & sandy clay loam & 2.65 & 1.48 & 0.19 & 0.28 & 47.42 & 41.32 & 6.09 & 19.49 & 0.84 & 0.00 & 0.42 & \\
\hline \multicolumn{19}{|c|}{ Cajaraneira (Spondia sp.) Orchard Area (COA)—Cambissolo Haplico Ta Eutrofico tipico } \\
\hline $0.00-0.10$ & 449 & 156 & 395 & 324 & 17.97 & clay loam & 2.32 & 1.17 & 0.29 & 0.35 & 53.71 & 49.61 & 4.09 & 24.40 & 2.06 & 0.59 & 1.51 & \\
\hline $0.10-0.20$ & 470 & 84 & 446 & 375 & 15.82 & sandy clay & 2.33 & 1.17 & 0.23 & 0.27 & 52.52 & 47.74 & 4.79 & 23.04 & 2.13 & 0.49 & 1.16 & 5.64 \\
\hline $0.20-0.30$ & 423 & 89 & 488 & 405 & 17.01 & clay & 2.58 & 1.20 & 0.27 & 0.32 & 54.71 & 50.25 & 4.46 & 24.61 & 2.04 & 0.56 & 1.43 & \\
\hline
\end{tabular}

Note. $\mathrm{CDW}=$ clay dispersed in water; $\mathrm{DF}=$ degree of flocculation; Dp = particle density; SD = soil density; GM = gravimetric moisture; $\mathrm{VM}=$ volumetric moisture; $\mathrm{TPd}=$ total porosity determined; $\mathrm{MiP}=$ microporosity; $\mathrm{MaP}$ = macroporosity; $\mathrm{AP}=$ aeration porosity; $\mathrm{WMD}=$ weighted mean diameter; $\mathrm{GMD}=$ geometric mean diameter; $\mathrm{SRP}=$ soil mechanical resistance to penetration; $\mathrm{BIR}=$ basic infiltration rate of water into the soil.

\subsection{Statistical Analysis}

The correlation matrix between the physical variables (Table 2) showed that the sand fraction had a negative correlation with clay dispersed in water (CDW), GM, VM, TPd, and MiP, and positive correlation with SD and BIR. SD presented a high correlation with GM, VM, TPd, MiP, MaP, AP, and BIR, denoting the dynamics of the soil physical structure. 
Table 2. Correlation matrix of physical indicators of the soils of the study areas

\begin{tabular}{|c|c|c|c|c|c|c|c|c|c|c|c|c|c|c|c|c|c|}
\hline Variable & Sand & Silt & Clay & CDW & DF & $\mathrm{Dp}$ & SD & GM & VM & TPd & MiP & $\mathrm{MaP}$ & $\mathrm{AP}$ & WMD & GMD & SRP & BIR \\
\hline Sand $\left(\mathrm{g} \mathrm{kg}^{-1}\right)$ & 1.00 & & & & & & & & & & & & & & & & \\
\hline Silt $\left(\mathrm{g} \mathrm{kg}^{-1}\right)$ & -0.24 & 1.00 & & & & & & & & & & & & & & & \\
\hline Clay $\left(\mathrm{g} \mathrm{kg}^{-1}\right)$ & -0.94 & -0.11 & 1.00 & & & & & & & & & & & & & & \\
\hline $\mathrm{CDW}\left(\mathrm{g} \mathrm{kg}^{-1}\right)$ & -0.88 & -0.10 & 0.94 & 1.00 & & & & & & & & & & & & & \\
\hline $\mathrm{DF}(\%)$ & -0.06 & -0.02 & 0.07 & -0.26 & 1.00 & & & & & & & & & & & & \\
\hline $\mathrm{Dp}\left(\mathrm{g} \mathrm{cm}^{-3}\right)$ & 0.43 & -0.11 & -0.40 & -0.43 & 0.08 & 1.00 & & & & & & & & & & & \\
\hline $\mathrm{SD}\left(\mathrm{g} \mathrm{cm}^{-3}\right)$ & 0.60 & -0.10 & -0.57 & -0.51 & -0.19 & 0.73 & 1.00 & & & & & & & & & & \\
\hline $\mathrm{GM}\left(\mathrm{g} \mathrm{g}^{-1}\right)$ & -0.55 & 0.04 & 0.55 & 0.53 & 0.10 & -0.53 & -0.83 & 1.00 & & & & & & & & & \\
\hline $\operatorname{VM}\left(\mathrm{cm}^{3} \mathrm{~cm}^{-3}\right)$ & -0.51 & -0.03 & 0.53 & 0.53 & 0.04 & -0.32 & -0.58 & 0.93 & 1.00 & & & & & & & & \\
\hline TPd (\%) & -0.79 & 0.12 & 0.77 & 0.64 & 0.30 & -0.62 & -0.87 & 0.72 & 0.53 & 1.00 & & & & & & & \\
\hline $\mathrm{MiP}(\%)$ & -0.77 & 0.03 & 0.77 & 0.69 & 0.14 & -0.52 & -0.80 & 0.67 & 0.49 & 0.94 & 1.00 & & & & & & \\
\hline $\mathrm{MaP}(\%)$ & -0.32 & 0.27 & 0.23 & 0.08 & 0.51 & -0.47 & -0.48 & 0.37 & 0.29 & 0.47 & 0.15 & 1.00 & & & & & \\
\hline $\mathrm{AP}(\%)$ & -0.71 & 0.09 & 0.69 & 0.61 & 0.13 & -0.55 & -0.80 & 0.62 & 0.39 & 0.93 & 0.98 & 0.17 & 1.00 & & & & \\
\hline WMD (mm) & -0.41 & -0.29 & 0.53 & 0.52 & -0.07 & -0.08 & -0.42 & 0.36 & 0.25 & 0.50 & 0.71 & -0.38 & 0.65 & 1.00 & & & \\
\hline GMD (mm) & 0.07 & -0.17 & -0.01 & -0.09 & 0.19 & 0.19 & 0.13 & -0.19 & -0.22 & 0.17 & 0.20 & -0.03 & 0.24 & 0.32 & 1.00 & & \\
\hline SRP (Mpa) & -0.32 & 0.23 & 0.25 & 0.18 & 0.19 & -0.13 & -0.11 & -0.06 & -0.10 & 0.26 & 0.26 & 0.09 & 0.24 & 0.13 & 0.21 & 1.00 & \\
\hline $\operatorname{BIR}\left(\mathrm{cm} \mathrm{h}^{-1}\right)$ & 0.59 & -0.02 & -0.59 & -0.46 & -0.39 & 0.71 & 0.78 & -0.52 & -0.32 & -0.79 & -0.63 & -0.68 & -0.63 & -0.18 & -0.01 & -0.22 & 1.00 \\
\hline
\end{tabular}

Note. $\mathrm{CDW}=$ clay dispersed in water; $\mathrm{DF}=$ degree of flocculation; $\mathrm{Dp}=$ particle density; $\mathrm{SD}=$ soil density; GM $=$ gravimetric moisture; $\mathrm{VM}=$ volumetric moisture; $\mathrm{TPd}=$ total porosity determined; $\mathrm{MiP}=$ microporosity; $\mathrm{MaP}$ = macroporosity; $\mathrm{AP}=$ aeration porosity; $\mathrm{WMD}=$ weighted mean diameter; $\mathrm{GMD}=$ geometric mean diameter; $\mathrm{SRP}=$ soil mechanical resistance to penetration; $\mathrm{BIR}=$ basic infiltration speed of water into the soil.

The principal component, and factorial analyses were performed in the data matrix consisting of 16 variables, requiring the removal of the microporosity due to multicollinearity. Table 3 shows the factorial loads after rotation of the data of soil physical indicators. The eigenvalues indicate the relative importance of each factor in the explanation of the variance of the set of attributes analyzed, showing factors in order of significance - significant factor loads with opposite signs denote variation in opposite direction (Arcoverde et al., 2015).

Then, factors 1, 2, 3 and 4 were selected because they met the criterion of eigenvalues above 1 . These factors accounted for $79.19 \%$ of the variance (Table 3 ).

Factor 1 (soil porosity) explained the largest part of total variance of the data, i.e., had the greatest influence. It consisted of the clay content, CDW, TPd, AP, VM, GM, varying in opposite direction to the sand content and SD, explaining $45.42 \%$ of the total data variance. Factor 2 (degree of flocculation; DF) consisted of DF and MaP, explaining $14.01 \%$ of the total variance of the data. Factor 3 (Aggregate) consisted of the GMD, and Factor 4 consisted of the SRP, explaining $11.29 \%$, and $8.47 \%$ of the total variance of the data, respectively (Table 3 ). 
Table 3. Matrix of factorial loads after orthogonal rotation by the Varimax Method for data of the soil physical indicators of the study areas.

\begin{tabular}{lllll}
\hline & \multicolumn{4}{c}{ Factorial loads } \\
\cline { 2 - 5 } Physical indicators & Factor 1 & Factor 2 & Factor 3 & Factor 4 \\
\cline { 2 - 5 } & Porosity & $\begin{array}{l}\text { Degree of } \\
\text { flocculation }\end{array}$ & Aggregates & $\begin{array}{l}\text { Soil mechanical } \\
\text { resistance to penetration }\end{array}$ \\
\hline Sand & $\mathbf{- 0 . 8 9}$ & -0.03 & 0.09 & -0.30 \\
Silt & 0.02 & 0.14 & -0.55 & 0.55 \\
Clay & $\mathbf{0 . 9 0}$ & -0.02 & 0.10 & 0.10 \\
CDW & $\mathbf{0 . 9 0}$ & -0.26 & -0.02 & 0.07 \\
DF & -0.06 & $\mathbf{0 . 7 9}$ & 0.30 & 0.05 \\
Dp & -0.61 & -0.34 & 0.33 & -0.03 \\
SD & $\mathbf{- 0 . 8 0}$ & -0.43 & 0.09 & 0.13 \\
GM & $\mathbf{0 . 7 7}$ & 0.26 & -0.17 & -0.42 \\
VM & $\mathbf{0 . 6 6}$ & 0.12 & -0.21 & -0.48 \\
TPd & $\mathbf{0 . 8 7}$ & 0.41 & 0.14 & 0.11 \\
MaP & 0.21 & $\mathbf{0 . 8 4}$ & -0.33 & 0.07 \\
AP & $\mathbf{0 . 8 4}$ & 0.20 & 0.27 & 0.14 \\
WMD & 0.62 & -0.29 & 0.62 & -0.07 \\
GMD & -0.07 & 0.16 & $\mathbf{0 . 7 9}$ & 0.24 \\
SRP & 0.20 & 0.09 & 0.14 & $\mathbf{0 . 7 7}$ \\
BIR & -0.64 & -0.63 & 0.03 & -0.09 \\
Eigenvalues & 7.27 & 2.24 & 1.81 & 1.36 \\
Total variance $(\%)$ & 45.42 & 14.01 & 70.72 & 79.19 \\
Accumulated variance $(\%)$ & 45.42 & 59.43 & & \\
\hline
\end{tabular}

Note. Factorial loads $\geq 0.65$ were significant.

The principal component analysis (PCA) showed a graphic representation of the distribution of variables in the unitary correlation circle (Figure 2a), and the distribution of the cloud of points representing the relationship between Factors 1 and 2 of the study areas (Figure 2b).

Practically all variables were near the unit circle, indicating greater contribution of the principal components to the more distant variables (Figure 2a). The inorganic fractions (sand, silt, and clay) were not close to the circle of correlations because the studied soils presented different textures despite their same classification up to the second categorical level ( $\mathrm{SiBCS}$ ), and the graph shows the predominance of the variables that better discriminated the environments, such as sand and clay. The graphs denoted the interrelationship between the variables and the predominant characteristics of each study area (Figure 2). 

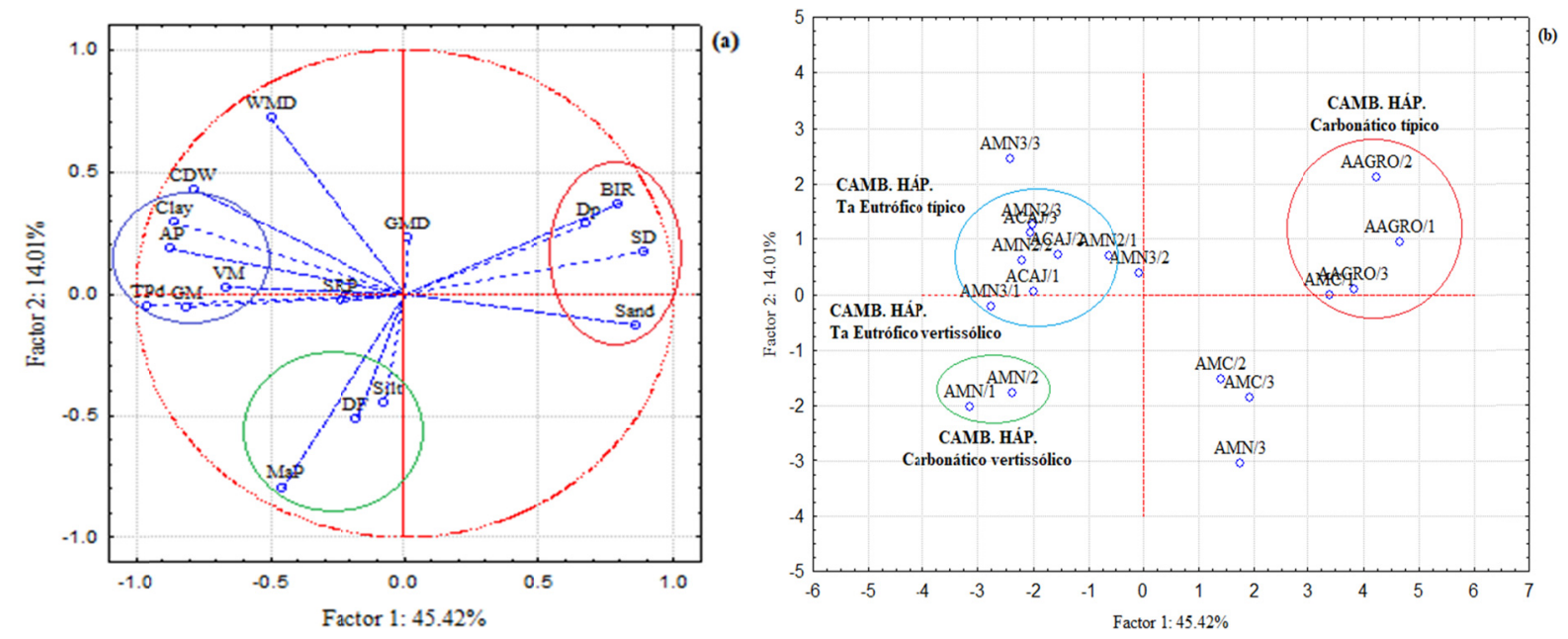

Figure 2. Distribution of the variables in the circle of correlations (a) and distribution of the cloud of points representing the relationship between Factors 1 and 2 (b)

The sand fraction, and SD were determinant for the description of Factor 1, with $45.42 \%$, because they were closer to the x-axis. Dp, and BIR had influence on the PCA (Figure 2a), with the most discriminating characteristics for the AEA, and CMA1 $(0.00-0.10 \mathrm{~m})$ areas, differentiating the Cambissolo Haplico Carbonático tipico from the other soils (Figure 2b). Thus, the sand content differentiated its texture (medium) from the others (clayey), showing a higher $\mathrm{Dp}$, since sand is composed mostly by quartz, higher SD (variation explained by the soil mineral composition and solid particle arrangement), and consequently, higher BIR, coinciding with the areas that presented the most water infiltration (Table 1).

However, Factor 1 presented the variables clay, AP, TPd, GM and VM as discriminant for the COA, NFA2, and NFA3 areas (Figure 2a), especially in the surface layer, representing the Cambissolo Háplicos Ta Eutrófico típico, and Cambissolo Haplico Ta Eutrofico vertissolico (Figure 2b), which presented the best conditions for the development of plants. This can be explained by their reduced anthropogenic interference, pedogenetic conditions, and higher clay fraction contents, which contributed to the predominance of micropores. This characteristic combined with the plant residues deposited to the soil surface by the falling of the cajaneiras leaves, also favored the increase in TPd, maintenance of the soil moisture, reduction of the Ds and, consequently, influenced the decreased SRP found in the surface layer (Table 1), as showed by the clustering of variables in the PCA (Figure 2a).

$\mathrm{DF}$ and MaP were determinant for the description of Factor 2. They were in the y-axis with $14.01 \%$ of discrimination, and silt had influence on the PCA (Figure 2a). These variables were important for the characterization of the native forest environment $(0.10-0.20 \mathrm{~m})$, which represents the Cambissolo Haplico Carbonatico vertissolico (Figure $2 b$ ).

Therefore, the inorganic fractions were determinant for the distinction of the environments, and had strong influence on other variables (Figures $2 a$ and $2 b$ ).

The Cambissolo Haplico Ta Eutrofico vertissolico was also represented in Factor 3 (11.29 \%), and 4 (8.47 \%) (Figure 3b), especially for the description of the NFA3, with GMD as discriminant (Figure 3a), mainly in the $0.20-0.30$ m layer, with the highest and most significant GMD. The absence of soil turning maintains the root system of plants, influencing positively the aggregation, since they cause approximation of mineral particles due to the pressure during their growth in porous spaces of the soil and release organic exudates (Ramos et al., 2010). 

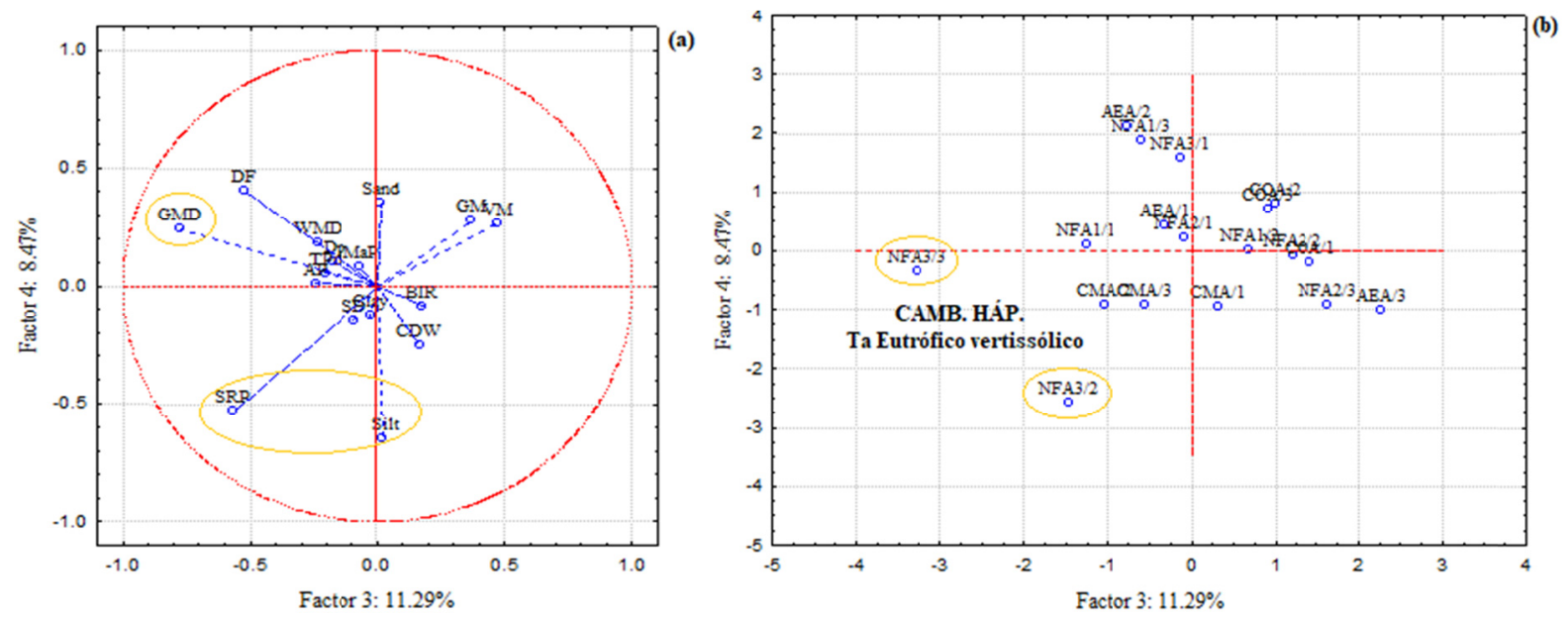

Figure 3. Distribution of the variables in the circle of correlations (a) and distribution of the cloud of points representing the relation between the Factors 3 and 4 (b)

The SRP discriminated Factor 4 (Figure 3a) for the NFA3 in the $0.10-0.20 \mathrm{~m}$ soil layer (Figure $3 \mathrm{~b}$ ) due to its higher SRP. The PCA showed that the silt fraction also influenced this environment, because of its higher content in this same layer (Table 1). This may be connected to the presence of animals that had access to this area during drought periods, or be characteristic of natural densification process, due to the weight of the upper soil layer, lack of soil turning, and higher presence of medium and fine particles, which contribute to a better particle arrangement, and consequently, a greater soil mechanical resistance to penetration. According to Resende et al. (2002), the silt fraction is important to soil crusting, which consists of a layer where fine sediments tend to be arranged in slides, causing compaction, and sealing of pores, hindering water infiltration and root penetration, therefore, soils rich in silts have a greater tendency to this phenomenon. It is an indicator of soil weathering degree, presenting higher proportions only in young soils, natural dispersion, with surface sealing, and natural susceptibility to erosion.

The variables that overlap each other had the same representativeness (Figure 3).

The clustering analysis denoted the number of groups formed by the same characteristics, where its reading is done from right to left, indicating the vertical scale of the level of difference (dissimilarity) between the variables, and homogeneous groups marked in increasing order of similarity in the horizontal axis (Figure 4).

The dendrogram analysis (Figure 4) showed the formation of distinct clusters for the land uses. A homogeneity level of $10 \%$ of dissimilarity was drawn, and three distinct groups were formed with the land uses, with homogeneous influence of soil physical attributes. The first cluster was formed by the native forest areas (NFA1-1, NFA2-1, and NFA3-1), and COA-1 area, in the surface layer, and NFA2-2, NFA3-2, CMA2, and CMA3 areas in the subsurface layer. The second cluster was formed by the subsurface layers $(0.00-0.10$ and $0.10-0.20 \mathrm{~m}$ ) of the NFA1-2, NFA2-3, NFA3-3, COA-2, and COA-3; it presented greater similarity and was the most expressive of the groups formed, presenting the COA as the most preserved area, since it had more similar characteristics to the native forest areas. The third cluster was formed by the third soil layer of the NFA1, all layers of the AEA, and surface layer of the CMA; this was probably because the soils of these areas had the same texture, and higher sand contents. 


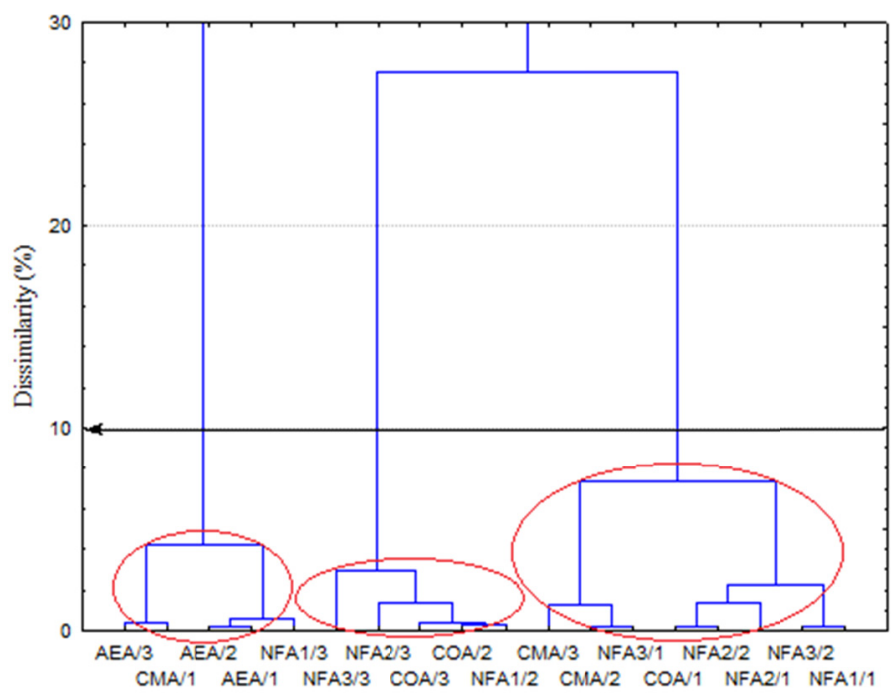

Figure 4. Vertical dendrogram of the soil distances matrix according to land uses, by the clustering using the Ward's method

Only variables that were significant (above 0.65) in Factors 1, 2, 3 and 4 of the matrices of factorial loads (clay, CDW, sand, TPd, AP, SD, GM, VM, MaP, DF, GMD and SRP) are shown in Table 4, because they are responsible for the greater weight in the classification of the variables. Soils were classified according to the performance of their physical indicators, with intervals defined as good, regular, or poor; some according to texture (simple, and complete diagrams), according to Kiehl (1979), Arshad et al. (1996), Prevedello (1996), Reynolds et al. (2002), Reichert et al. (2003), Pereira et al. (2010), Ferreira (2010), and Prado (2013), important for the sustainability of farming systems.

Table 4. Reference values of the ten soil physical indicators for good, regular, and poor performance groups from the most relevant Factors of the factorial analysis

\begin{tabular}{|c|c|c|c|c|c|c|}
\hline \multirow{2}{*}{ Indicators } & \multirow{2}{*}{ Unity } & \multirow{2}{*}{ Simple texture } & \multirow{2}{*}{ Complete texture } & \multicolumn{3}{|c|}{ Performance groups } \\
\hline & & & & Good & Regular & Poor \\
\hline Clay* & $\left(\mathrm{g} \mathrm{kg}^{-1}\right)$ & - & - & $350-450$ & $350-200$ & $<200$ \\
\hline $\mathrm{CDW} / \mathrm{DF}^{*}$ & $\left(\mathrm{~g} \mathrm{~kg}^{-1}\right) /(\%)$ & - & - & 100------. & ------------- & -0.00 \\
\hline Sand* & $\left(\mathrm{g} \mathrm{kg}^{-1}\right)$ & - & - & $400-600$ & $600-800$ & $>800$ \\
\hline $\mathrm{TPd}^{*}$ & $(\%)$ & - & - & $40.0-70.0$ & $35.0-40.0$ & $<35.0$ \\
\hline $\mathrm{AP} *$ & $(\%)$ & - & - & $15.0-30.0$ & $10.0-15.0$ & $<10.0$ \\
\hline \multirow{4}{*}{$\mathrm{SD}^{*}$} & \multirow{4}{*}{$\left(\mathrm{g} \mathrm{cm}^{-3}\right)$} & \multirow{3}{*}{ Clayey } & clay loam & $<1.55$ & $1.60-1.75$ & $>1.75$ \\
\hline & & & sandy clay & $<1.49$ & $1.49-1.58$ & $>1.58$ \\
\hline & & & clayey & $<1.39$ & $1.39-1.47$ & $>1.47$ \\
\hline & & Medium & sandy clay loam & $<1.60$ & $1.60-1.75$ & $>1.75$ \\
\hline \multirow{4}{*}{ GM/VM * } & \multirow{4}{*}{$\left(\mathrm{g} \mathrm{g}^{-1}\right) /\left(\mathrm{cm}^{3} \mathrm{~cm}^{-3}\right)$} & \multirow{3}{*}{ Clayey } & clay loam & $0.28-0.30$ & $0.22-0.28$ & $<0.22$ \\
\hline & & & sandy clay & $0.30-0.40$ & $0.28-0.30$ & $<0.28$ \\
\hline & & & clayey & $0.42-0.55$ & $0.40-0.42$ & $<0.40$ \\
\hline & & Medium & sandy clay loam & $0.32-0.40$ & $0.22-0.32$ & $<0.22$ \\
\hline $\mathrm{MaP}$ & $(\%)$ & - & - & $20.0-25.0$ & $17.0-20.0$ & $<17.0$ \\
\hline GMD & $(\mathrm{mm})$ & - & - & $1.45-1.60$ & $1.45-1.00$ & $<1.00$ \\
\hline SRP & $(\mathrm{MPa})$ & - & - & $0.00-2.00$ & $2.00-4.00$ & $>4.00$ \\
\hline
\end{tabular}

Note. $\mathrm{CDW}=$ clay dispersed in water; $\mathrm{DF}=$ degree of flocculation; $\mathrm{TPd}=$ total porosity determined; $\mathrm{AP}=$ aeration porosity; $\mathrm{SD}=$ soil density; $\mathrm{GM}=$ gravimetric moisture; $\mathrm{VM}=$ volumetric moisture; $\mathrm{MaP}=$ macroporosity; GMD = geometric mean diameter; SRP $=$ soil mechanical resistance to penetration. *Most relevant attributes in factor 1 , which represents $45.42 \%$ of the data variance (tie-breaking criterion). Reference values according to Kiehl (1979), Arshad et al. (1996), Prevedello (1996), Reynolds et al. (2002), Reichert et al. (2003), Pereira et al. (2010), Ferreira (2010), and Prado (2013). 
According to the reference ranges of the ten physical indicators in the performance groups (Table 4), the three layers of all Cambissolos Haplicos under different land use and managements were classified as good, despite the soils of the NFA1 (0.20-0.30 m), CMA, and AEA presented the most altered attributes. This can be attributed to the pedogenetic conditions, which influenced their medium texture, with predominance of the sand fraction (606 to $691 \mathrm{~g} \mathrm{~kg}^{-1}>600$ to $800 \mathrm{~g} \mathrm{~kg}^{-1}$, regular) and, consequently, affected the attributes Dp, SD and BIR (PCA), indicating low aggregate stability (GMD $=0.0$ to $0.97>1 \mathrm{~mm}$, poor), $\mathrm{DF}$ ( 2 to $30.95 \%$, poor), and moisture (VM $=0.16$ to $0.20 \mathrm{~cm}^{3} \mathrm{~cm}^{-3}<0.22 \mathrm{~cm}^{3} \mathrm{~cm}^{-3}$, poor). However, they had good performance because the number of physical indicators classified as good was higher in Factor 1, which is the most important, representing $45.42 \%$ of the variance of the data, which includes SD, TPd, and AP.

\section{Conclusions}

The most relevant physical attributes to discriminate Cambissolos Haplicos are clay and sand fractions, and the structural attributes porosity, degree of flocculation, aggregates, and soil mechanical resistance to penetration.

The physical and structural attributes of the Cambissolos Haplicos were, in general, preserved when compared to the current condition of native forests, even under different land use and managements. However, the soils under the Native Forest Area 1 (0.20-0.30 m soil layer), Conventional Management Area, and Agroecological Area naturally denoted fragility in aggregate stability and degree of flocculation, mainly due to the predominance of the sand fraction.

The Cajaraneira (Spondia sp.) Orchard Area presented more favorable structural physical conditions to the development of agricultural crops, especially in the surface layer, and in relation to clay, total porosity, aeration porosity, gravimetric moisture, volumetric moisture, and soil mechanical resistance to penetration.

The sand fraction, and soil density discriminated the Agroecological, and Conventional Management Areas, representing the Cambissolo Haplico Carbonático tipico. The clay fraction, aeration porosity, total porosity, gravimetric moisture, and volumetric moisture discriminated the Cajaraneira (Spondia sp.) Orchard Area, Native Forest Area 2, and Native Forest Area 3, representing the Cambissolo Haplico Ta Eutrofico tipico, and the Cambissolo Háplico Ta Eutrófico vertissólico, the latter being also discriminated by the geometric mean diameter, and soil mechanical resistance to penetration. The degree of flocculation, and macropores discriminate the Native Forest Area 1, representing the Cambissolo Haplico Carbonatico vertissolico.

\section{Acknowledgements}

The present study was carried out with support from Improvement of Higher Education Personnel Brazil (CAPES)-Financing Code 001. We thank Pro Rectory Research and Graduate Studies (PROPPG) and the Graduate Program in Soil and Water Management (PPGMSA) of the Federal Rural University of the Semi-Arid (UFERSA).

\section{References}

Araújo, E. A., Ker, J. C., Neves, J. C. L., \& Lani, J. L. (2012). Qualidade do solo: Conceitos, indicadores e avaliação. Revista Brasileira de Tecnologia Aplicada nas Ciências Agrárias, 5(1), 187-206. https://doi.org/ 10.5777/PAeT.V5.N1.12

Araújo, R., Goedert, W. J., \& Lacerda, M. P. C. (2007). Qualidade de um solo sob diferentes usos e sob cerrado nativo. Revista Brasileira de Ciência do Solo, 3, 1099-108. https://doi.org/10.1590/S0100-0683200700 0500025

Arcoverde, S. N. S., Salviano, A. M., Olszevski, N., Melo, S. B., Cunha, T. J. F., Giongo, V., \& Pereira, J. S. (2015). Qualidade Física de Solos em uso agrícola na Região Semiárida do Estado da Bahia. Revista Brasileira de Ciência do Solo, 39(5), 1473-1482. https://doi.org/10.1590/01000683rbcs20140282

Arshad, M. A., Lowery, B., \& Grossman, B. (1996). Physical test for monitoring soil quality. In J. W. Doran \& A. J. Jones (Eds.), Methods for assessing soil quality (pp. 123-142). Madison: Soil Science Society of America. https://doi.org/10.2136/sssaspecpub49.c7

ASAE (American Society of Agricultural Engineers). (2004). Soil cone penetrometer (p. 2). ASAE, St. Joseph.

Bernardo, S., Soares, A. A., \& Mantovani, E. C. (2008). Manual de irrigação (8th ed., p. 625). Viçosa: UFV.

Brady, N. C., \& Weil, R. R. (2013). Elementos da Natureza e Propriedades dos Solos (3rd ed.). Porto Alegre: Bookman. 
D'andréa, A. F., Silva, M. L. N., Curi, N., \& Ferreira, M. M. (2002). Atributos de agregação indicadores da qualidade do solo em sistemas de manejo na região dos Cerrados no sul do estado de Goiás. Revista Brasileira de Ciência do Solo, 26, 1047-1054. https://doi.org/10.1590/S0100-06832002000400022

Dexter, Ar. (2004). Soil physical quality-Part I. Theory, effects of soil texture, density, and organic matter, and effects on root growth. Geoderma, 120, 201-14. https://doi.org/10.1016/j.geoderma.2003.09.004

Ferreira, M. M. (2010). Caracterização física do solo. In Q. J. V. Lier (Ed.), Física do solo. Sociedade Brasileira de Ciência do Solo (pp. 1-27). Viçosa.

Jacomine, P. K. T., Silva, F. B. R., Formiga, R. A., Almeida, J. C., Beltrão, V. A., Pessoa, S. C. P., \& Ferreira, R. C. (1971). Levantamento exploratório-Reconhecimento de solos do Estado do Rio Grande do Norte (Boletim Técnico, 21, p. 531). Recife, DPP/DA. Convênio MA/DNPEA/SUDENE/DRN, MA/CONTAP/ USAID/BRASIL.

Kiehl, J. (1979). Manual de edafologia-Relações solo-planta (p. 492). São Paulo: Agronômica Ceres.

Marinho, A. C. C. S., Portela, J. C., Silva, E. F., Dias, N. S., Sousa Junior, F. S., Silva, A. C., \& Silva, J. F. (2016) Organic matter and physicochemical attributes of a cambisol under different agricultural uses in a semi-arid region of Brazil. Australian Journal of Crop Science, 10, 32-41.

Oliveira, P. R., Centurion, J. F., Centurion, M. A. P. C., Rosseti, K. V., Ferraudo, A. S., Franco, H. B. J., ... Bárbaro Júnior, L. S. (2013). Qualidade estrutural de um Latossolo Vermelho submetido à compactação. Revista Brasileira de Ciência do Solo, 37(3), 604-612. https://doi.org/10.1590/S0100-06832013000300006

Pereira, F. S., Andrioli, I., Pereira, F. S., Oliveira, P. S., Centurion, J. F., Falqueto, R., \& Martins, A. L. S. (2011). Qualidade física de um Latossolo Vermelho submetido a sistemas de manejo avaliado pelo índice S. Revista Brasileira de Ciência do Solo, 35, 87-95. https://doi.org/10.1590/S0100-06832011000100008

Pereira, L. S., Valero, J. A. J., Buendía, M. R. P., \& Martín-Benito, J. M. T. (2010). El riego e sus tecnologías (p. 296). Albacete: CREA-UCLM.

Prado, H. (2013). Pedologia fácil: aplicações em solos tropicais (4th ed., p. 284). Piracicaba.

Prevedello, C. L. (1996). Física do solo com problemas resolvidos (p. 446). Curitiba: SEAFS.

Ramos, F. T., Monari, Y. C., Nunes, M. C. M., Campos, D. T. S., \& Ramos, D. T. (2010). Indicadores de qualidade em um Latossolo Vermelho-Amarelo sob pastagem extensiva no pantanal matogrossense. Revista Caatinga, 23, 112-120.

Reichert, J. M., Reinert, D. J., \& Braida, J. A. (2003). Qualidade dos solos e sustentabilidade de sistemas agrícolas. Revista Ciências Ambientais, 27, 29-48.

Resende, M., Curi, N., Rezende, S. B., \& Corrêa, S. A. (2002). Pedologia: Base para distinção de ambientes (4th ed., p. 338). Viçosa, MG, NEPUT.

Reynolds, W. D., Bowman, B. T., Drury, C. F., Tana, C. S., \& Lu, X. (2002). Indicators of good soil physical quality: Density and storage parameters. Geoderma, 110, 131-46. https://doi.org/10.1016/S0016-7061(02) 00228-8

Santos, H. G., Jacomine, P. K. T., Anjos, L. H. C., Oliveira, V. A., Lumbreras, J. F., Coelho, M. R., ... Oliveira, J. B. de. (2009). Sistema brasileiro de classificação de solos (3rd ed., p. 353). Brasília: Embrapa.

StatSoft. (2004). Statistica Version 7.0. StatSoft. Retrieved from http://www.statsoft.com

Teixeira, P. C., Donagemma G. K., Wenceslau, A. F., \& Teixeira, G. (2017). Manual de Métodos de Análise de Solo (3rd ed., p. 573). Rio de Janeiro: Embrapa Solos.

\section{Copyrights}

Copyright for this article is retained by the author(s), with first publication rights granted to the journal.

This is an open-access article distributed under the terms and conditions of the Creative Commons Attribution license (http://creativecommons.org/licenses/by/4.0/). 